\title{
Classification of Unelaborated Culinary Products: Scientific and Culinary Approaches Meet Face to Face
}

Ugo D’Ambrosio ${ }^{\mathrm{a}, \mathrm{b}^{*}}$, Marta Vila ${ }^{\mathrm{c}^{*}}$, Ferran Adriàd, Laura Bayés-García ${ }^{\mathrm{e}}$, Sergio Calsamiglia $^{\mathrm{f}}$, Pere Castells ${ }^{\mathrm{c}}$, Oriol Castro ${ }^{\mathrm{d}}$, Teresa Garnatje ${ }^{\mathrm{b}}$, Joaquim Gosálbez ${ }^{\mathrm{g}}$, Joan Jofre $^{\mathrm{h}}$, Abel Marinéc, Lourdes Reig ${ }^{\mathrm{i}}$, Màrius Rubiralta ${ }^{\mathrm{j}}$, Eduard Xatruch ${ }^{\mathrm{d}}$, and Joan Vallès ${ }^{1 \dagger}$.

${ }^{a}$ Laboratori de Botànica - Unitat Associada CSIC, Facultat de Farmàcia, Universitat de Barcelona, Avinguda Joan XXIII s/n, 08028 Barcelona, Catalonia, Spain. E-mail: ud6@kentforlife.net, joanvalles@ub.edu

${ }^{b}$ Institut Botànic de Barcelona (IBB-CSIC-ICUB), Passeig del Migdia s/n, Parc de Montjuïc, 08038 Barcelona, Catalonia, Spain. E-mail: tgarnatje@ibb.csic.es

'Unitat UB-Bullipèdia, Campus de l'Alimentació de Torribera, Universitat de Barcelona, Prat de la Riba 171, 08921 Santa Coloma de Gramenet, Catalonia, Spain. E-mail: marta.vila@ub.edu,perecastells@ub.edu,abelmarine@ub.edu

${ }^{\mathrm{d}}$ ElBulliLab, ElBulliFoundation, Mèxic 17 4-5, 08004 Barcelona, Catalonia, Spain. Email: ferrisa@telefonica.net, oriol@oriolcastro.com, eduardxatruch@gmail.com

eDepartament de Cristal-lografia, Mineralogia i Dipòsits Minerals, Universitat de Barcelona, Martí i Franquès s/n, 08028 Barcelona, Catalonia, Spain. E-mail: laurabayes@ub.edu

${ }^{\mathrm{f}}$ Departament de Ciència Animal i dels Aliments, Universitat Autònoma de Barcelona, Edifici V, Campus de la UAB, 08193 Bellaterra (Cerdanyola del Vallès), Catalonia, Spain. E-mail: SergioCalsamiglia@uab.cat

'Departament de Biologia Animal, Universitat de Barcelona, Avinguda Diagonal 643 08028 Barcelona, Catalonia, Spain. E-mail: jgosalbez@ub.edu

hepartament de Microbiologia, Universitat de Barcelona, Avinguda Diagonal 643 08028 Barcelona, Catalonia, Spain. E-mail: jjofre@ub.edu

iDepartament d'Enginyeria Agroalimentària i Biotecnologia, Universitat Politècnica de Catalunya, Esteve Terrades 8, 08860 Castelldefels, Catalonia, Spain. E-mail: lourdes.reig@upc.edu

jCampus de l'Alimentació de Torribera, Universitat de Barcelona, Prat de la Riba 171, 08921 Santa Coloma de Gramenet, Catalonia, Spain. E-mail: mrubiralta@ub.edu

* Both authors contributed equally to this work.

† Corresponding author: Joan Vallès. Laboratori de Botànica - Unitat Associada CSIC, Facultat de Farmàcia, Universitat de Barcelona, Avinguda Joan XXIII s/n, 08028 Barcelona, Catalonia, Spain. joanvalles@ub.edu

Short title: Scientific \& Culinary Classifications of Food Products 


\begin{abstract}
The ongoing academization of gastronomic studies indicates the necessity for a commonly accepted classification system for cooks that does not contradict scientific approaches. This work discusses the fundamentals used to classify unelaborated food products by chefs and scientists; proposes taxonomic gastronomy as a new interdisciplinary framework that studies the taxonomy surrounding gastronomy; and presents a categorization of unelaborated food products that follows commonly accepted culinary criteria yet avoids contradiction with scientific knowledge. As little literature focuses on these issues, and similar experiences are scarce, we conclude that further cross-disciplinary endeavors such as this will continue to be greatly fruitful.
\end{abstract}

Keywords: gastronomy, academization of cooking, classification systems, unelaborated culinary products, plants, fungi, animals, microorganisms, minerals, interdisciplinary approach.

\title{
Introduction
}

One of the oldest and most significant endeavors that human beings have embarked on is to name and classify a myriad of objects surrounding them, especially those used for specifically relevant purposes (Berlin 1992). Outstanding among such entities are living organisms and mineral products used as food and drink, because they have been and continue to be particularly germane for survival and human evolution. In addition, the classification of foodstuffs has been highly important not only on a general scale, but especially for professional cooks, as well as—although many times indirectly-for scientists of various academic fields.

We address in this paper unelaborated products, understanding by this food products that are used directly in cooking activities, not after a process that could 


\section{unelaborated product, but its juice or a jam made with them are elaborated products.}

Folk, professional and scientific classifications of unelaborated food products (and their parts) are not requiredforcibly always coincidental between them-or even within them-as the ways in which distinct groups of people observe and conceptualize food can be remarkably different. At the same time, systems and outcomes of such classifications are, certainly, in constant evolution according to the knowledge and beliefs people have in a particular sphere and moment. As an example, the scientific classification of the elements of nature in three kingdoms, i.e., animals, plants and minerals, proposed in 1675 by Nicolas Lemery (Lemery 1713), and popularized by Karl von Linnaeus (Linnaeus 1766),_common in textbooks up to the second half of the $19^{\text {th }}$ century (Hogg 1860; Haeckel 1866), was replaced by newer proposals with the development of microscopy, cell biology and genetics, amongst other disciplines and with the incorporation of other major biological groups such as monera (bacteria), protists and fungi (Margulis 1974; Margulis and Schwartz 1982; Woese et al. 1990).

New advances in science and cooking_—with the ongoing "academization" of gastronomic studies_-reflected in many regulated studies for professional cooks, even at a university degree level_ point out to the necessity for a commonly accepted system of classification for cooks, that does not contradict scientific approaches, yet very little has been done in this respect. Such a classification system could benefit from previous ones, in order to create a solid and robust categorization structure, which is nevertheless flexible and adaptablive to change. Furthermore, to our knowledge no attempt has been done to analyze and conciliate the classification of food products between scientific and culinary approaches. In fact, no scientific literature seems to address the caveats of 
classification systems within the sphere of professional cooks, while cooks have usually not addressed the lack of consensus within culinary classifications of food products.

Based on these premises, the aims of the present work are: (i) to discuss the fundamentals used to classify unelaborated food products and their parts by professional cooks on one side, and by scientists (өrganismic biologists studying organisms along with geologists) on the other; (ii) to propose a new interdisciplinary frameworktermed here as taxonomic gastronomy - that studies and analyses the taxonomy surrounding gastronomy (e.g., products, tools, techniques), within a systemic approach to food studies; and, (iii) to offer a consensual and flexible framework for the categorization of unelaborated food products (and their parts) derived from the direct collaboration of chefs and academics, that which follows commonly accepted culinary criteria yet avoids contradiction with scientific knowledge.

In what follows, we present the methodology employed in this research, followed by the conceptual background on existing classification systems from both the culinary and scientific points of view. A taxonomy of gastronomy is proposed later, ensued by the consensus classification system reached by co-authoring scientists and cooks, with concluding remarks.

\section{Methodology}

This work has been carried out transdisciplinarily by elBulliLab culinary team (elBulliFoundation, led by Chef Ferran Adrià) and the UB-Bullipedia academic unit at the Food and Nutrition Torribera Campus of the Universitat de Barcelona (University of Barcelona). Academic collaborations from the Universitat de Barcelona included: the Laboratory of Botany (Faculty of Pharmacy), the Departments of Animal Biology and Microbiology (Faculty of Biology), along with the Department of Crystallography and 
Mineralogy (Faculty of Geology). Equally, the Institut Botànic de Barcelona (Botanical Institute of Barcelona, CSIC-ICUB), the Department of Animal and Food Sciences (Universitat Autònoma de Barcelona, Autonomous University of Barcelona), and the Department of Agri-Food Engineering and Biotechnology (Universitat Politècnica de Catalunya, Polytechnic University of Catalonia) also participated during the whole taxonomic process. These teams have defined the multifaceted nature of the resulting understandings and classification system.

This classificatory process began in 2013 by a team of cooks from elBulliLab and a small team from the UB-Bullipedia Unit — by then recently created-with an initial analysis of the state of the art. Such analysis was used to build a first proposal of classification that merged culinary and scientific perspectives. In March-April 2013 the a team of experts from the UB-Bullipedia Unit was created in order to bring together the team of cooks from elBulliLab with academics from the UB-Bullipedia Unit. Various meetings were organized, one every two months approximately. In the light of the conclusions reached in these meetings, elBulliLab team created new versions of the classification, which were then sent to the UB-Bullipedia Unit experts for corroboration. Following this methodology, a first agreement was reached in September 2013; however, it was later on adapted. The second and final agreement was reached in July 2014 and the classification was first presented in September 2014 in the new undergraduate joint degree in Culinary and Gastronomic Sciences offered by the Universitat de Barcelona and the Universitat Politècnica de Catalunya.

In this article, we propose a classification of food products (and their parts) with the idea of converting it into a collectively accepted classification by disparate types of professionals. In concrete, we focus here on unelaborated products (i.e., unprocessed foods such as the apple-tree, brewer's yeast, chicken or sea salt), leaving the 
classification of elaborated products (e.g., cider or jam), tools (e.g., pots and pans) and techniques (e.g., ethanol fermentation or jellification) for future work. Moreover, the main target group of this endeavor cannot go unmentioned, i.e., professional cooks. The proposed classification has been built from a culinary perspective and with a culinary purpose, that is, to organize the culinary products in an efficient, practical and understandable way for cooks. However, this is not incompatible with a general and interdisciplinary consensus. Despite this clear cooking-oriented perspective, this classification has considered the scientific views of different fields. In addition, we have limited our scope here mostly to European cuisine, to further delimit our analysis of unelaborated food products.

\section{Conceptual background in the taxonomy of foodstuffs}

Interestingly, culinary scientists, anthropologists, ethnotaxonomists or other cognitive scientists have not studied the food classification systems used amongst professional cooks, while folk taxonomies of food products or scientific classifications have been analyzed in much greater detail (Berlin 1967; Anderson 1980; Anderson 2014). We focus first on the poorly-documented conceptual background in the professional classifications of food, followed by a few paragraphs on scientific taxonomies, while leavtting aside folk conceptualizations from our examination-scrutiny in this article, as they have been analyzed elsewhere (Messer 1981; Nichter 1986; Manderson 1986; Douglas 1997).

Theoretically, professional cook vocabularies, classifications and categorizations could be considered intermediate between folk and scientific ones, in the sense that they are not carried out with a systematic scientific method, but require the application of some technical aspects that are not necessary in folk thinking (Figure 1). In addition, 
such gastronomic taxonomies are restricted to a small group of people; $e_{i}$, that is, they correspond to a specialized or professionalized knowledge.

\section{INSERT FIGURE 1}

As previously stated, academically speaking little has been written about how chefs and professional cooks classify food. Historically, cookbooks are collections of recipes, generally only numbered and not grouped under any criteria, such as the Ancient Rome book De re culinaria (Apicius 1541) or the medieval Libre de Sent Soví (Grewe 1979). From the first attempts to the present day, culinary classifications by professionals have been varied and heterogeneous, while following distinct systematization criteria: La Varenne (La Varenne 1651), for instance, had listed seasonal meat products according to religious dates (e.g., meats from Easter to Saint John's Day); Menon organized foods according to elaborations (e.g., pâté) (Menon 1749); Escoffier classified them according to products, elaborations or even the courses of meals without distinguishing between them (e.g., fishes, sauces, appetizers) (Escoffier 1903). Until recently, these classifications were not explicitly commented upon and were simply used as a base for structuring recipes in books.

More latrecently, the nouvelle cuisine chef Michel Bras, following the tradition of French cooks including the innovations of this school, classified dishes in categories such as vegetables, meats, soups, appetizers and desserts (Bras 2002). Chef Joan Roca (Roca 2014), in turn, used the following categories: vegetables; fruits; herbs, spiecies, flowers and sprouts; at the pantry; fish; seafood and cephalopods; and meats. Since Ferran Adrià became chef of elBulli at 1985, his team showed an increased interest in the classification of culinary products and gastronomic knowledge in general. The 
initial volume of the first catalogue of dishes eatalogue-published, already presents a classification of culinary products: waters, nuts, fish, eggs, preserved foods, wines, etc (Adrià et al. 2002). When Adrià ended elBulli's culinary activity (in 2011), he devoted $\underline{\text { himself even more to thehis reflection -shared with members of the academy- on several }}$ gastroculinary aspects, among which the classification of products, which he did not consider to be sufficiently resolved. An evolution of such ideas, reflections and work is the classification presented in this article.

Classification systems of food products amongst scientists vary according to the discipline, be it biology, nutrition, food science and technology, agronomy, geology, chemistry or physics. The bases for such taxonomies are in direct relation to the core subject in each discipline, varying from organisms, nutrients, agronomic units, minerals, molecules, to state and change just to name just a few. New approaches and methodologies allow constant evolution of such concepts and their categorizations. For instance, conceptual frameworks and categorization proposals for living organisms in science have varied greatly through time (Morton 1981). The first classification systems were far from using biological characters; Pedanius Dioscorides $\left(1^{\text {st }}\right.$ century AD), for example, classified plants, animals and inorganic products by their uses. Later on, artificial systems such as the one created by Karl von Linnaeus in plants, started to consider biological traits, but only a few of them. The natural method-formulated in its more complete form by Augustin Pyrame de Candolle (19 ${ }^{\text {th }}$ century) —aimed to use a representative diversity of traits for classification purposes. After Charles Darwin $\left(19^{\text {th }}\right.$ century), phylogenetic systems could adopt evolutionary concepts. Later on, important efforts have been maddene to incorporate to systematics not only morphological characters, but others such as chemical, cytogenetic as well as genomic (Stuessy 2011). 
The above-mentioned classical classification of living organisms in a twokingdom system was first questioned by Haeckel (1866), who, additionally to plants and animals, established the kingdom of protista, which comprised mostly single-celled organisms such as the protozoa, bacteria, and some algae and fungi. From then on, several changes have been made in this classification, with the proposal of different numbers of kingdoms (Margulis and Chapman 2009), which facilitate classifying all kinds of organisms into discernible groupings. Nevertheless, the biggest paradigm change in biological classification whas-been facilitated by the discovery of the polymerase chain reaction (PCR) (Saiki et al. 1985), and its great potential in DNA sequencing, leading, from the 1990s, to molecular systematics. To summarize, nowadays, based on and developed from Woese et al. (1990), living organisms are classified into three big domains (two of which are composed of prokaryotes, i.e., microorganisms without a nucleus), and what was classically considered as plants or animals are nowadays split into four kingdoms. Detailed-level classifications are today in process such as the 'Tree of life project' (Maddison and Schulz 2007), but the simple long-established animal/plant dichotomy prevailing until the $20^{\text {th }}$ century, clearly is no longer of use. For a thorough analysis of the evolution of taxonomic systems in biology during the last century, see Williams and Forey (2004). Mineral products are kept apart from living organisms as it has been the case from the onset ofancient the three kingdoms of nature of antiquity.

\section{Taxonomic gastronomy: A new approach to professional cooking and}

\section{science}

Over the past years, gastronomic sciences have become a new frontier in academic fields and the professional world of cooks, with increasing holistic and transdisciplinary 
approaches to food and gastronomy (Caporaso and Formisano 2015). Nonetheless, the relationship between science and cooking is long-standing and has provided a foundation for the academization of cooking, although classification systems from both sides have not yet converged. In the $19^{\text {th }}$ century, explicit references existed already to such a relationship (Accum 1821; Liebig 1847; Kellogg 1895).

In the $20^{\text {th }}$ century, two crucial moments are the talk by Nicholas Kurti at the Royal Society titled "The physicist in the kitchen" in 1969, and when in 1992 the term "molecular gastronomy" was coined in the framework of the "Workshop on Molecular and Physical Gastronomy” by the scientists Harold McGee (1984), Hervé This (1993), and Nicholas Kurti (1988), the three most relevant figures of the molecular gastronomy movement. In 2007, Chef Ferran Adrià was the recipient of an Honorary Doctorate from the Department of Chemical Engineering at the Universitat de Barcelona and in the same year he delivered his first conference at Harvard University entitled "Cooking and Science with Ferran Adrià". This conference was the first step towards the launching in 2010 of the annual course on "Science and Cooking" in the Physics Department at Harvard University. Also wWorth mentioning is-alse the emergence of the field of computational gastronomy, which consists in applying massive data analysis (big data) to gastronomic knowledge (Ahnert 2013). Specialized workshops such as "Computational Gastronomy: Food in the Age of Data" are proof of the interest of this new research field. Philosophy and arts are also turning their focus ointo gastronomy; an example of this is the subject "Gustatory Aesthetics" within the undergraduate studies of Philosophy at the Universitat Autònoma de Barcelona.

Moreover, university level studies on cooking and gastronomy are being created, such as the ones offered at the Università degli Studi di Scienze Gastronomiche (University of Gastronomic Sciences in Bra, Italy), the Master of Liberal Arts in 
Gastronomy at Boston University Metropolitan College or the new Bachelor's Degree in Culinary and Gastronomic Sciences offered by the Universitat de Barcelona and the Universitat Politècnica de Catalunya. These are just a few examples of what we can call the emerging academization of cooking. Last but not least, another sign of the emergence of culinary science is the increase in SCI- and/or SSCI-indexed journals dealing with professional cooking and the science behind it, such as Flavour, Food, Culture and Society, Food Research International__or Food Reviews International or International Journal of Gastronomy \& Food Science. This academization process has led to the emergence, in the intersection of the areas of science and cooking, of a thought collective (Fleck, 1935), i.e. a community of people participating in a mutual exchange of ideas and intellectual opinion, which has been, among other things, the breeding ground of the consensus classification here presented. In fact, the abovementioned academization process means the crystallization of a new academic discipline, which is interdisciplinary by nature and entails the need for a reconceptualization of concepts coming from other disciplines. For example, the parsley is seen and has to be defined from a different perspective in integrative gastronomic $\underline{\text { sciences than in botany or in cooking as considered separately. Gastronomic sciences }}$ cannot be the sum of their sibling disciplines, but require a change of paradigm and a process of distillation, to which the present paper-built by representatives of different approaches converging in the gastronomic sciences thought collective-aims to contribute.

Following this trend, we propose here a new branch within the systemic research approach to gastronomy: taxonomic gastronomy. Taxonomic gastronomy encompasses the scientific study of the description, identification, nomenclature, and classification of culinary products (unelaborated and elaborated), along with tools and techniques used 
for cooking. Such a definition is especially suited (but not exclusively) for systems of food classification by professional cooks in present and past times. As molecular gastronomy did (see above), taxonomic gastronomy requires a similar framework that combines contributions from two major human spheres: the culinary arts and a myriad of scientific disciplines, mainly physical, analytical and organic chemistry, biology, geology, nutrition, and food science and technology.

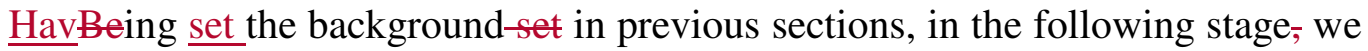
present the taxonomic scheme of the classification agreed upon between chefs and academics, along with its different divisions, subdivisions and components.

\section{Consensus classification for unelaborated culinary products}

The classification system consensually obtained by scientists and expert cooks for unelaborated products is based on consecutive subcategories, beginning from living beings vs. inorganic materials, further subdivided into worlds and, in the case of living beings, into specific organisms and their anatomical parts (Table 1).

\section{INSERT TABLE 1}

Within unelaborated food products, two mutually exclusive categories were established: living beings and inorganic materials, the former with three subcategories (here known as "worlds") and the latter with two. On one side, the three living worlds include a joint category of plants and fungi (considered together, but as distinct groups, owing to the tradition of them being studied under the discipline of Botany), and two additional categories, that is, animals and microorganisms. A previous consensual arrangement following the kingdoms of living organisms was discarded, as a complete 
agreement does not exist among biologists on the number and delimitation of these kingdoms and, in addition, we did not find any of those classifications to be, in our opinion, functional and simple enough for culinary products. We adopted the term "world" to define each unit, because it did not bear any biological taxonomical connotation and it is clear, evocative and intuitive. Within each group of organisms, according to their main habitat along with morphological and phylogenetic relations, distinct categories can be found, where the primary level corresponds to the biological species in question (e.g., lemon tree or trout), and following levels vary according to distinct groups of organisms (e.g., peel of lemon or trout fillet). Such levels, which are very relevant to cooks, reflect one of the many contributions of gastronomy to the consensual taxonomy presented. On the other side, within inorganic materials two worlds were established: the world of waters and the world of minerals, and within them further categories were created according to their origin. For greater detail on the taxonomy and categorization within living beings see Annex-Table 21, and for inorganic materials see Annex Table $3 z$.

\section{I- Living beings}

For all living beings, we basically follow the most recent biological classifications, some of them still in construction, at least at the lower taxonomic levels, according to the evolution of molecular datasets. Comprehensive projects, such as Tree of Life (Maddison and Schulz 2007), along with some other restricted to specific biological groups, such as the Angiosperm Phylogeny Website for plants (Stevens 2013), the List of Prokaryotic names with Standing in Nomenclature for bacteria (LPSN 2015), and Introduction to the Metazoa for animals (UCMP 2015), may provide ideas on the state of the art in biological systematics. However, this classification being conceived as a 
consensual one between different professional worlds (scientific and gastroculinary), these strictly biological scenarios could not be completely followed. For example, we could not use the structuring of life in several kingdoms (Margulis and Chapman 2009), because it did not work at a convenient and convincing level to both scientific and eøok culinary professionals. Therefore, the classification of living beings was finally structured in what we called "worlds" (to avoid words such as "kingdom" or "domain", with more biological connotation): plants and fungi (with both groups clearly mentioned); animals; and microorganisms. This classification does not strictly fit with current biological systematics and phylogenetics, but is understandable for all professionals and does not fall outside biological logics. As shown later, some major groups in the plant and fungi, and animal domains have been established on the basis of habitats, which does not constitute a biological systematic criterion, but is adequate for cooking professionals, and makes the incorporation of new gastronomic groups, whenever necessary, easier. In another case, cooks had to avoid the useing of the term family for some food products (and to replace it with category or group), because such a term has a different and concrete sense in biological systematics. In the following paragraphs we explain and exemplify the solutions adopted for the different groups of living beings. The distinction between wild and cultivated (plants and fungi) or raised (animals), not relevant in biological classification (irrespective of the existence of infraspecific taxa and races), has been adoapted, asince it is meaningful for culinaryeook professionals.

\section{a) Plants and fungi}

Following the above-mentioned habitat criterion, within the world of plants and fungi (Annex Table 21A), a first distinction between terrestrial and aquatic organisms is 
maddene, establishing four subgroups, two for terrestrial (plants and fungi) and two for aquatic (macroalgae, and bryophytes and vascular plants); note thatn in the terrestrial habitat we do not explicitly mention bryophytes, as they are comprised within plants, but in the aquatic habitat we must separate the three stated categories, all of them belonging to plants, and fungi are not mentioned, since to date no aquatic fungus has culinary uses.

Within terrestrial plants a distinction is made between grasses, subshrubs, shrubs, lianas and trees. Within fungi, three groupings are proposed: ascomycota, basidiomycota and lichens. Within macroalgae, three types are distinguished: green, red and brown algae. Aquatic plants, all herbs, do not contain further subgroupings. It is to be noted that different criteria have been used in the classification of different organisms, for the sake of consensus. For plants the differentiation does not fit at all with taxonomical categories, but with life forms, which are much more intuitive. For instance, the distinction between pteridophytes and spermatophytes or that between gymnosperms and angiosperms has been avoided, as well as the lower categories (e.g. monocots, core eudicots, asterids...), because it was meaningless for cooking professionals. Conversely, for fungi and macroalgae, the basic biological categories have been followed (e.g. ascomycetes, red algae).

The aspects commented above deal with what we have called primary level, i.e., the whole plant or fungal organism. The secondary level consists of parts of plants or fungi (e.g. leaves, branches with leaves, fungal stipe) and the tertiary is composed of parts of parts of those organisms (e.g. seeds, peduncles). Those levels contain different categories depending on the primary level. These parts of plants or fungi, again, do not exactly fit plant and fungal morphology, but are not against it, and function without problems for culinaryeook professionals. One case is the parts we named "fruits, 
fructifications and infructescences"; for cooking professionals, "fruits" was convenient, but they did not object to the larger and multiple term, which was correct from a scientific point of view. See Annex-Table $2+A$ for greater detail and some more examples than those here provided.

In some cases, the search for a compromise between scientific and culinaryeook professionals lead to the proposal of a neologism. Cooks termed "albedo" the white tissue found in figs (Ficus carica L.), by analogy with the similar part in citric fruits (Citrus sp.). This was not correct from a botanical standpoint, as oranges and their relatives are fruits, but figs are infructescences. Finally, we agreed in proposing the term "pseudoalbedo" for such a structure in figs. Nevertheless, terminological proposals of this kind have to be further analyzed also with linguists.

\section{b) Animals}

The world of animals (Annex Table 24B) establishes an arrangement that, being scientifically correct, allows cooks to classify animals and their derived products easily and comprehensively. An agreement was reached to cluster animals according to their habitat: aerial, terrestrial, aquatic and terrestrial-aquatic. In each environment up to four levels have been contemplated, from primary to quaternary.

A following step included taking into consideration the different groups with a culinary interest, to be included in each of these categories. In the primary level (whole organism), the zoological groups selected are presented in Annex Table 2t. Within each environment, the criterion used to arrange categories has been to consider most consumed culinary groups. Such ordering allows, as new gastronomic groups arise, to add to the corresponding type. In some cases, such a classification has required certain adaptations to reality. Insects are probably the most complex case, with several species 
being edible. When we think about insects we imagine terrestrial organisms that move in the air, hence being included within aerial organisms. But most edible insects have terrestrial larvae, which are generally more gastronomically valued than adults, while larvae live longer than adults. That makes it difficult to include them undoubtedly within the aerial or terrestrial habitat, hence its being more practical to consider their aerial habitat when the adult is eaten, and the terrestrial in the case of larvae. Other examples include mollusks, which comprise terrestrial and aquatic organisms, and within the latter, marine and freshwater. In such circumstance each species is located where it corresponds. On the other hand, reptiles, generally terrestrial (e.g., lizards, snakes), also consist of taxa such as turtles that can be terrestrial and aquatic. Marine turtles, even having an aquatic life, reproduce oin the land. The opposite occurs amongst amphibians, which most of which have a terrestrial life (e.g., toads, frogs) yet reproduce in aquatic environments.

While ordering groups within categories in each habitat, criteria of biological taxonomy have prevailed. This has been easier in certain cases but had to be adapted in others. Birds, for instance, are situated in the aerial environment. Within such grouping, organization follows taxonomic criteria: Galliformes, Estrucioniformes, Passeriformes, Anseriformes, etc. The advantage behind such a structure is that, if a bird starts to have culinary interest and is not represented by the existing orders, it only needs to be added up. Internal classification for mollusks has been simple as there exist three zoological groups: bivalves (e.g., clams), gastropods (e.g., terrestrial and marine snails) and cephalopods (e.g., squid, cuttlefish and octopus). In the terrestrial environment all are gastropods, and in the aquatic there is only the need to differentiate marine vs. freshwater species. In other taxa, adapting to culinary criteria was more practical. Such is the case of mammals. In such a cluster, a bio-taxonomic ordering was followed: 
bovids, porcines, etc. Nonetheless, for bovids-a group that includes most edible mammals (e.g., veal, sheep, goat and buffalo)-such grouping under its taxonomic name, popularly evoking mostly cow and related animals, is not discernible enough for a cook. In such case the taxon has been subdivided into bovine bovids (e.g., veal, cow and ox), ovine bovids (e.g., sheep, lamb), caprine bovids (e.g., kid, goat) and other bovids (e.g., buffalo, bison). For crustaceans-all aquatic-we have opted for a practical classification, taking into account the means of locomotion. Three categories have been created: swimmers (moving in a water column such as shrimp, lobster and langoustine), walkers (moving on top of the substrate such as brown crab and velvet crab) and cirripedia (living fixed to the substrate such as barnacles). Not all crustaceans are marine; are also freshwater species such as the river crab. For In the case of other groups with very specific characteristics, for instance echinoderms (sea cucumbers), tunicates (sea potato) or cnidarians (sea anemones, jellyfish), ordering has been easier.

The secondary level includes the morphological parts easily identifiable externally, in which the animal can be divided, i.e., head, body and extremities. Nevertheless, not all animals have their bodies anatomically organized in the same manner and this affects the number and structure of pieces used in the kitchen. For instance, adult insects have their bodies divided in head, thorax (includes legs) and abdomen, while larvae have their head differentiated from the rest of the body. In crustaceans, decapods (the most valued, i.e., shrimp, crab) have their body divided in cephalothorax (fusion of head and thorax including legs) and abdomen (known as tail). For fish, the body is simplified and the head, body and fins are recognized. The most complex case is for terrestrial vertebrates, such as birds and mammals where main parts are identifiable but their utilization requires the establishment of more parts. The neck belongs to the trunk yet gastronomically is treated separately. Further, a distinction is 
also needed between anterior extremities (wings, shoulders) from posterior (thigh) although usually, combinations of parts occur (e.g., forequarter, hindquarter and half carcass).

The tertiary level refers to the parts of the parts (secondary level), with examples such as the brain or the tongue as parts of the head. In the world of animals, in contrast to that of plants and fungi, a quaternary level was necessary. It corresponds to the tissues, such as tendons, which can come from different parts of the animal body. Not all groups of animals have the four above-described levels. An interesting challenge has been to describe the derived products. At the beginningfirst, it seemed clear to define a derived product as a product obtained from an organism without causing it any injury. It could include some resins, pollen or nectar in the case of plants and eggs or milk in the case of animals. The problem appears when facing immature eggs or blood of animals, which cannot be obtained without damaging them. In this case we decided to treat them as quaternary level items.

\section{c) Microorganisms}

Even thoughif it has some important representatives, the world of culinary microorganisms (Annex 1Table 2C) is much smallhorter. It has been structured in four groups: viruses, to date without culinary use; bacteria (including archaea), comprising organisms such as lactobacillus and the blue-green algae or cyanobacteria (among which Spirulina sp. is well known in cooking); protozoa and microalgae, to which, for instance, Chlorella sp. belongs-te; and microfungi (unicellular and filamentous ones), including yeasts and molds. In this case the transactions for a consensus have led to consider in the microbiological world some animals (protozoa), some plants (microalgae) and some fungi (microfungi), apart from the genuine microorganisms 
(viruses, archaea and bacteria). Their microscopic condition, clearly intuitive, has primed over the strict biological classification, although not being in contradiction with it. As it is logical, no different (primary, secondary...) levels are distinguished in this world.

\section{II- Inorganic materials}

Regarding the inorganic materials classification (Annex 2Table 3), two different worlds have been considered, i.e., waters and minerals. For the two cases, previously used classifications in gastronomic scenaerioes have been modified and adapted by applying scientific standards. As an example, scientific terms such as geological origin or crystal morphology and crystal size were employed in order to develop the classification of waters and minerals, respectively. The main criterion used to carry out such $\underline{\mathrm{a}}$ classification distinction in bothe two cases was the origin of the material. However, some additional aspects related to each world should be taken into account.

\section{d) Waters}

Most commonly used classifications for potable waters are based on their composition in major cations (such as $\mathrm{Na}^{+}, \mathrm{Ca}^{2+}$ or $\left.\mathrm{Mg}^{2+}\right)$ and anions $\left(\mathrm{CO}_{3} \mathrm{H}^{-}, \mathrm{Cl}^{-}, \mathrm{SO}_{4}{ }^{2-}, \mathrm{F}^{-}, \mathrm{SH}^{-}\right.$, etc.) (Domenico and Schwartz 1990), which strongly depends on the travelled paths through their evolutionary history. In the present work, we classified the world of waters (Annex 2Table 3A) according to their origin: superficial, subterraneous and seawater. The superficial waters category includes river, lake and glacier waters (all of them being non-carbonated waters), whereas the subterraneous waters category comprises natural mineral and natural spring waters, which can be non-carbonated or carbonated through natural and/or artificial methodologies. Subterraneous waters 
eventually emerge from below the Earth's surface or they can be forced by using specific techniques. Nevertheless, the main difference between natural spring and natural mineral waters resmaidens ien the fact that natural spring waters are not characterized by their mineral composition, se-thusat ithey can become variable. As to natural mineral waters, only two actions are permitted: i) to modify and normalize the carbon dioxide content; and, ii) to reduce or eliminate the presence of unstable compounds in order to avoid unpleasant flavors and/or colors.

\section{e) Minerals}

The most commonly used classifications for the world of minerals (Annex 2Table 3B) is based on their chemical composition and structure (Gaines et al. 1997), where, according to new actualizations, biominerals, understood as minerals produced by the activity of living things (e.g. bones, shells), may also be considered. In the present work, we focused on common salt (sodium chloride, with mineral name of halite), which is commonly used in cooking, and $_{2}$ depending on its origin, it may provide specific characteristics to the end food product. As an example, one may note that pink or black colored fossil salt may occur due to the presence of other minerals impurities. In the different types of salt obtained from salt lakes and salt flats, such as flower of salt or salt flakes, the different crystal morphologies may play dominant roles for determining some physical properties (e.g. rapid solubility) which may be directly applicable to specific food products.

As in other scientific classifications from the periodic table of elements to molecular taxonomy of living beings, the current classification will evolve according to new parameters and criteria, while maintaining its culinary application. Nonetheless, the essence of the classification will not change drastically. 


\section{Concluding remarks}

The existing gap in the taxonomy of professional cooking, with the interaction between cooks and scientists has allowed the creation of a combined system of classification that is useful for cooks and consistent with scientific knowledge. Such a new taxonomy establishes five worlds (plants and fungi, animals, microorganisms, waters and minerals) each with a variety of hierarchical subcomponents, mutually exclusive and subdivided into distinct levels according to their parts.

The resulting classification generates a flexible ordering, highly practical, that allows modifications and new introductions without changing its main structure. Hence, it is not a closed system but a taxonomy allowing all incorporations that may rise. Being conceived to be flexible enough to adapt to change when needed, it intends to be valuable for professional cooks as well as for food scientists, amongst others.

Despite major background differences between botanists, zoologists, microbiologists, mineralogists, nutritionists, food scientists, agronomists, chemists, linguists, cooks, and people from other disciplines, a diverse team has worked side by side on the project, obtaining an overall agreement in the resulting classification.

We hope that this classification system will be useful in the classroom, as well as at home and in restaurants, for chefs, bartenders and foodies. This classification is already part of the curriculum of the new undergraduate studies in Culinary and Gastronomic Sciences (Universitat de Barcelona and Universitat Politècnica de Catalunya) with the idea of being later included in other culinary studies.

We are now in the process of the categorization of most common ingredients in Western cuisine-over a milliard-into the different ranks, levels and categories. Future work in this taxonomic effort will involve the classification of elaborated products, i.e., 
those having undergone some kind of processing (e.g., bread or guacamole), in addition to cooking tools, techniques, and other culinary aspects. We are also working oin the terminological analysis and standardization of all the terms that appear in the classification. We are focusing, at this point, on the Catalan language and we are working together with the linguistic services of the Universitat de Barcelona and TERMCAT, the center for terminology in Catalan of the Government of Catalonia.

\section{Acknowledgements}

We are grateful to the people that participated in the different stages of the creation of the proposed classification of unelaborated products: Pere Arpa, Salvador Brugués, Maria Teresa Calvet, Oriol Cano, Vinyet Capdet, Núria Castells, Miguel Ángel Cuevas, Àngels Egea, Christian Escribà, Xavier Franco, Carles Gaig, Airy Gras, Oriol Ivern, Marta Juncadella, Nandu Jubany, Claudi Mans, Evarist March, Fabián Martín, Ada Parellada, Paco Pérez, Pere Planagumà, Fina Puigdevall, Mariana Ramirez de Arellano, Albert Raurich, Josep Maria Ribé, Joan Roca, Enric Rosich, Enric Rovira, Carme Ruscalleda, Xano Saguer, Patricia Schmidt, Montserrat Serra, Carles Tejedor, Sergio Torres and Javier Torres, among others. Samuel Pyke (Barcelona's Botanical Garden) is thanked for the revision of English language. This work was carried out in the framework of the agreement between the Universitat de Barcelona and elBulliFoundation signed on 23 October 2012 and was subsidized by the Catalan government (2009SGR0403, 2014SGR1241, 2014SGR7, 2014SGR514, 2014SGR1315, 2014SGR1208, 2014SGR1480 and 2014SGR623).

Ugo D'Ambrosio is an ethnobiologist, particularly interested ien food plants. 
Marta Vila is a linguist, working on computational gastronomy and gastronomic knowledge management.

Ferran Adrià is a cook, formerly responsible for one of the best considered restaurants in the world, now leading a foundation on food aspects.

Laura Bayés-García is an assistant professor on crystallography interested ien crystallographic aspects of food materials.

Sergio Calsamiglia is a professor of animal production working on aspects of animal food products.

Pere Castells is a chemist, very actively involved in putting together science and kitchen.

Oriol Castro is a cook of Ferran Adrià's school, now co-leading two highly considered restaurants.

Teresa Garnatje is a researcher on botany working on evolutionary botany and on ethnobotany, with particular attention to food plants.

Joaquim Gosálbez is a professor of zoology $y_{2}$ interested ien the applications of animal science to food products. 
Joan Jofre is a professor of microbiology, having addressed his interest to some food aspects of microorganisms.

Abel Mariné is a professor of food science and nutrition, who is implicated in gastronomic aspects.

Lourdes Reig is a lecturer on zoology specialized in fishes, with interest in food issues.

Màrius Rubiralta is a professor off organic chemistry, who coordinates the food sciences campus of his university.

Eduard Xatruch is a cook of Ferran Adrià's school, now co-leading two highly considered restaurants.

Joan Vallès is a professor of botany with research focuses on plant systematics and evolution and ethnobotany, with special interest ien food plants.

\section{Disclosure statements}

Authors confirm that they have no competing interests with the publication of this work, which is original and has not been published elsewhere.

\section{References}

Accum, F. (1821). Culinary Chemistry, Exhibiting the Scientific Principles of Cookery, with Concise Instructions for Preparing Good and Wholesome Pickles, Vinegar, Conserves, Fruit Jellies with Observations on the Chemical Constitution and 
Nutritive Qualities of Different Kinds of Food; London: published by R. Ackermann. 380 pp.

Adrià, F., Soler, J. and Adrià, A. (2002). El Bulli 1998-2002. ARA Llibres: Barcelona. $493 \mathrm{pp}$.

Ahnert, S. E. (2013). Network analysis and data mining in food science: the emergence of computational gastronomy. Flavour, 2: 4.

Anderson, E. N. (1980). Heating and Cooling Foods in Hong Kong and Taiwan. Social Science Information, 19 (2): 237-268.

Anderson, E.N. (2014). Everyone Eats: Understanding Food and Culture; $2^{\text {nd }}$ ed.; NYU Press: New York and London. 295 pp.

Apicius, C. (1541). Caelii Apitii... De re culinaria libri decem. B. Platinae ... De tuenda ualetudine, natura rerum \& popinae scientia libri X. Pauli AEginetae De facultatibus alimentorum tractatus; Lugduni [Lyon]: apud Seb. Gryphium. 314, [14] pp.

Berlin, B. (1967). Categories of Eating in Tzetzal and Navaho. International Journal of American Linguistics, 33: 1-6.

Berlin, B. (1992). Ethnobiological Classification: Principles of Categorization of Plants and Animals in Traditional Societies; Princeton University Press: Princeton. 335 pp.

Bras, M. (2002). Essential Cuisine; Ici La Pr: Woodbury, 272 pp.

Caporaso, N. and Formisano, D. (2015). Developments, Applications and Trends of Molecular Gastronomy among Food Scientists and Innovative Chefs. Food Reviews International. DOI: 10.1080/87559129.2015.1094818.

Domenico, P. A. and Schwartz, F. W. (1990). Physical and Chemical Hydrogeology; John Wiley \& Sons: New York. 824 pp. 
Douglas, M. (1997). Deciphering a Meal. In Food and Culture: A Reader; Counihan, C.; Esterik, P. V. (eds.). Routledge: New York and London. pp. 135-158.

Escoffier, A. (1903). Le Guide Culinaire: Aide-mémoire de Cuisine Pratique; Imprimerie de Lagny: Paris. 790 pp.

Fleck, L. (1935). Entstehung und Entwicklung einer wissenschaftlichen Tatsache. Einführung in die Lehre vom Denkstil und Denkkollektiv, Benno Schwabe und Co.; Lothar Schäfer und Thomas Schnelle (Hrsg. und Vorwort): Basel. XXXX pp.

Gaines, R. V., Skinner, H. C., Foord, E. E., Mason, B. and Rosenzweig, A. (eds.). (1997). Dana's New Mineralogy; $8^{\text {th }}$ ed.; John Wiley \& Sons, Inc.: New York. $1872 \mathrm{pp}$.

Grewe, R. (ed.). (1979). Libre de Sent Soví: Receptari de Cuina; Barcino, Fundació Jaume I: Barcelona. 250 pp.

Haeckel, E. (1866). Generelle Morphologie der Organismen; Georg Reimer: Berlin, vol. II. $462 \mathrm{pp}$.

Hogg, J. (1860). On the Distinctions of a Plant and an Animal and on a Fourth Kingdom of Nature. Edinburgh New Philosophical Journal (New Series). 12: 216-225.

Kellogg, E. E. (2010). Science in the Kitchen; Qontro Classic Books, 610 pp. [1893.]

Kurti, N. and G. Kurti. (1988). But the Crackling is Superb, An Anthology on Food and Drink by Fellows and Foreign Members of the Royal Society; Hilger: Bristol. 261 pp.

La Varenne, P. (1651). Le Cuisinier françois où est enseigné la maniere d'apprêter toute sorte de viandes, de faire toute sorte de patisseries \& de confitures : reveu \& augmentée d'un traité de confitures seiches \& liquides \& pour apprêter des festins aux quatre saisons de l'année; Lyon: chez Jacques Canier. 457 [i.e. 459], [9] pp. 
Lemery, N. (1713). Cours de chymie: contenant la maniere de faire les operations qui sont en usage dans la medecine par une methode facile: avec des raisonnemens sur chaque operation, pour l'instruction de ceux qui veulent s'appliquer à cette science; $11^{\text {th }}$ ed.; Lyon: chez Louis de Claustre. 836, [4] pp.

Liebig, J. (1847). Researches on the Chemistry of Food; Taylor and Walton: London. 208 pp.

Linnaeus, C. (1766).Systema Naturae: sive Regna Tria Naturae Systematice Proposita per Classes, Ordines, Genera et Species; 12 ${ }^{\text {th }}$ ed.; Holmiae: Stockholm. 1327 pp.

LPSN (List of Prokaryotic Names with Standing in Nomenclature). (2015). Classifications of Prokaryotes (Bacteria). Available from: http://www.bacterio.net/-taxonomy.html. (Accessed 4 Oct. 2015).

Maddison, D. R. and Schulz, K. S. (eds.). (2007). The Tree of Life Web Project. Available from: http://tolweb.org. (Accessed 1 Oct. 2015).

Manderson, L. (1986). Food Classification and Restriction in Peninsular Malaysia: Nature, Culture, Hot and Cold. In Manderson, L. (ed.). Shared Wealth and Symbol: Food, Culture, and Society in Oceania and Southeast Asia; Cambridge University Press: Cambridge, pp. 128-143.

Margulis, L. (1974). Five-kingdom Classification and the Origin and Evolution of Cells. Evolutionary Biology, 7: 45-78.

Margulis, L. and Chapman, M. J. (2009). Kingdoms \& Domains: An Illustrated Guide to the Phyla of Life on Earth; $4^{\text {th }}$ ed.; Academic Press - Elsevier: Amsterdam, 659 pp.

Margulis, L.; Schwartz, K. V. (1982). Five Kingdoms. An illustrated Guide to the Phyla of Live on Earth; W. H. Freeman and Co: San Francisco, 338 pp. 
McGee, H. (1984). On Food and Cooking: The Science and Lore of the Kitchen. New York: Scribner, 684 pp.

Menon. (1749). La Science du maître d'hotel cuisinier: avec des observations sur la connoissance \& proprietés des alimens. Paris: chez Paulus-du-Mesnil, 552, [8] pp.

Messer, E. (1981). Hot-cold Classifications: Theoretical and Practical Implications of a Mexican Study. Social Science Medicine, 15(b), 133-145.

Morton, A.G. (1981). History of Botanical Science. An Account of the Development of Botany from Ancient Times to the Present Day; London Academic Press: London, $474 \mathrm{pp}$.

Nitchter, M. (1986). Modes of Food Classification and the Diet-Health Contingency: A South Indian Case Study. In Food, Society, and Culture. Khare, R.S., Rao, M.S.A., Eds. Carolina Academic Press: Durham, North Carolina, pp. 185-221.

Roca, J. (2014). Cuina amb Joan Roca. Tècniques Bàsiques per Cuinar a Casa; Planeta: Barcelona, $350 \mathrm{pp}$.

Saiki, R.K., Scharf, S., Faloona, F., Mullis, K.B., Horn M G.T., Erlich, H.A. and Arnheim, N. (1985). Enzymatic Amplification of Beta-Globin Genomic Sequences and Restriction Site Analysis for Diagnosis of Sickle Cell Anaemia. Science, 230: 1350-1354.

Stevens, P. F. (2013).Angiosperm Phylogeny Website. Version 13, September 2013. Available from: http://www.mobot.org/MOBOT/research/APweb/. (Accessed 3 Oct. 2015).

Stuessy, T.F. (2011). Multiple Sources of Comparative Data for Creative Monography. In Monographic Plant Systematics. Fundamental Assessment of Plant Biodiversity; Stuessy, T.F., Lack, H.W., Eds.; Ruggell ARG Gantner Verlag KG: Liechtenstein, pp 33-47. 
This, H. Les Secrets de la casserole. Éditions Belin: Paris, (1993). 222 pp.

UCMP (University of California Museum of Paleontology). (2015). Introduction to the Metazoa: Systematics. Available from: http://www.ucmp.berkeley.edu/phyla/metazoasy.html. (Accessed 1 Oct. 2015).

Williams, D.M. and Forey, P.L. (2004). Milestones in Systematics. CRC Press: Boca Raton, Florida. 312 pp.

Woese, C.R., Kandler, O. and Wheelis, M.L. (1990). Towards a natural system of organisms: proposal for the domains Archaea, Bacteria, and Eucarya. Proceedings of the National Academy of Sciences of the United States of America, 87: 4576-4579. 
Figure caption

Figure 1: Classification systems of food (simplified) by different human groups 
Table 1: Classification of unelaborated products: living beings

\begin{tabular}{|c|c|c|c|c|c|c|c|c|}
\hline $\begin{array}{l}\text { Unelaborated } \\
\text { product }\end{array}$ & World & $\begin{array}{l}\text { Main } \\
\text { habitat }\end{array}$ & $\begin{array}{l}\text { Group of } \\
\text { organisms }\end{array}$ & $\begin{array}{c}\text { Primary level } \\
\text { (biological } \\
\text { species) }\end{array}$ & $\begin{array}{c}\text { Secondary } \\
\text { level }\end{array}$ & Tertiary level & $\begin{array}{c}\text { Quaternary } \\
\text { level }\end{array}$ & $\begin{array}{l}\text { Examples of } \\
\text { levels* }\end{array}$ \\
\hline \multirow[t]{10}{*}{ Living beings } & \multirow[t]{10}{*}{ Plants and fungi } & \multirow[t]{8}{*}{ Terrestrial } & \multirow[t]{5}{*}{ Plants } & Grass & \multirow{5}{*}{$\begin{array}{l}\text { Root, stem, } \\
\text { stem with } \\
\text { leaves, leaves, } \\
\text { flowers \& } \\
\text { inflorescences, } \\
\text { flowering aerial } \\
\text { parts, and fruits } \\
\text { and } \\
\text { infructescences, } \\
\text { seeds }\end{array}$} & \multirow{5}{*}{$\begin{array}{c}\text { Types of } \\
\text { specific organs, } \\
\text { specific tissues } \\
\text { and parts } \\
\text { within organs }\end{array}$} & \multirow{5}{*}{$\mathrm{n} / \mathrm{a}$} & $\begin{array}{l}\text { Triticum } \\
\text { aestivum } \\
\text { (wheat)-seed- } \\
\text { endosperm }\end{array}$ \\
\hline & & & & Subshrub & & & & $\begin{array}{l}\text { Rosmarinus } \\
\text { officinalis } \\
\text { (rosemary)- leaf- } \\
\text { parenchyma }\end{array}$ \\
\hline & & & & Shrub & & & & $\begin{array}{l}\text { Sambucus nigra } \\
\text { (elderberry)- } \\
\text { inflorescence- }\end{array}$ \\
\hline & & & & Liana & & & & $\begin{array}{l}\text { Humulus lupulus } \\
\text { (hops)- } \\
\text { inflorescence }\end{array}$ \\
\hline & & & & Tree & & & & $\begin{array}{l}\text { Mangifera } \\
\text { indica (mango)- } \\
\text { fruit-mesocarp }\end{array}$ \\
\hline & & & \multirow[t]{3}{*}{ Fungi } & Ascomycota & $\begin{array}{l}\text { For some } \\
\text { species: stalk, } \\
\text { cap }\end{array}$ & \multirow{3}{*}{$\begin{array}{c}\text { Specific tissues } \\
\text { and parts } \\
\text { within organs }\end{array}$} & \multirow{3}{*}{$\mathrm{n} / \mathrm{a}$} & $\begin{array}{l}\text { Tuber } \\
\text { melanosporum } \\
\text { (black truffle) }\end{array}$ \\
\hline & & & & Basidiomycota & Stalk, cap & & & $\begin{array}{l}\text { Agaricus } \\
\text { bisporus } \\
\text { (portobello } \\
\text { mushroom)- } \\
\text { stalk \& cap }\end{array}$ \\
\hline & & & & Lichens & $\mathrm{n} / \mathrm{a}$ & & & \\
\hline & & \multirow[t]{2}{*}{ Aquatic } & \multirow[t]{2}{*}{ Macroalgae } & Green algae & \multirow[t]{2}{*}{$\begin{array}{l}\text { Rhizoid, cauloid } \\
\text { and phylloid }\end{array}$} & \multirow{2}{*}{$\begin{array}{l}\text { Specific tissues } \\
\text { and parts } \\
\text { within organs }\end{array}$} & \multirow[t]{2}{*}{$\mathrm{n} / \mathrm{a}$} & $\begin{array}{l}\text { Ulva lactuca } \\
\text { (sea lettuce)- } \\
\text { phylloid }\end{array}$ \\
\hline & & & & Red algae & & & & $\begin{array}{l}\text { Chondrus } \\
\text { crispus }\end{array}$ \\
\hline
\end{tabular}




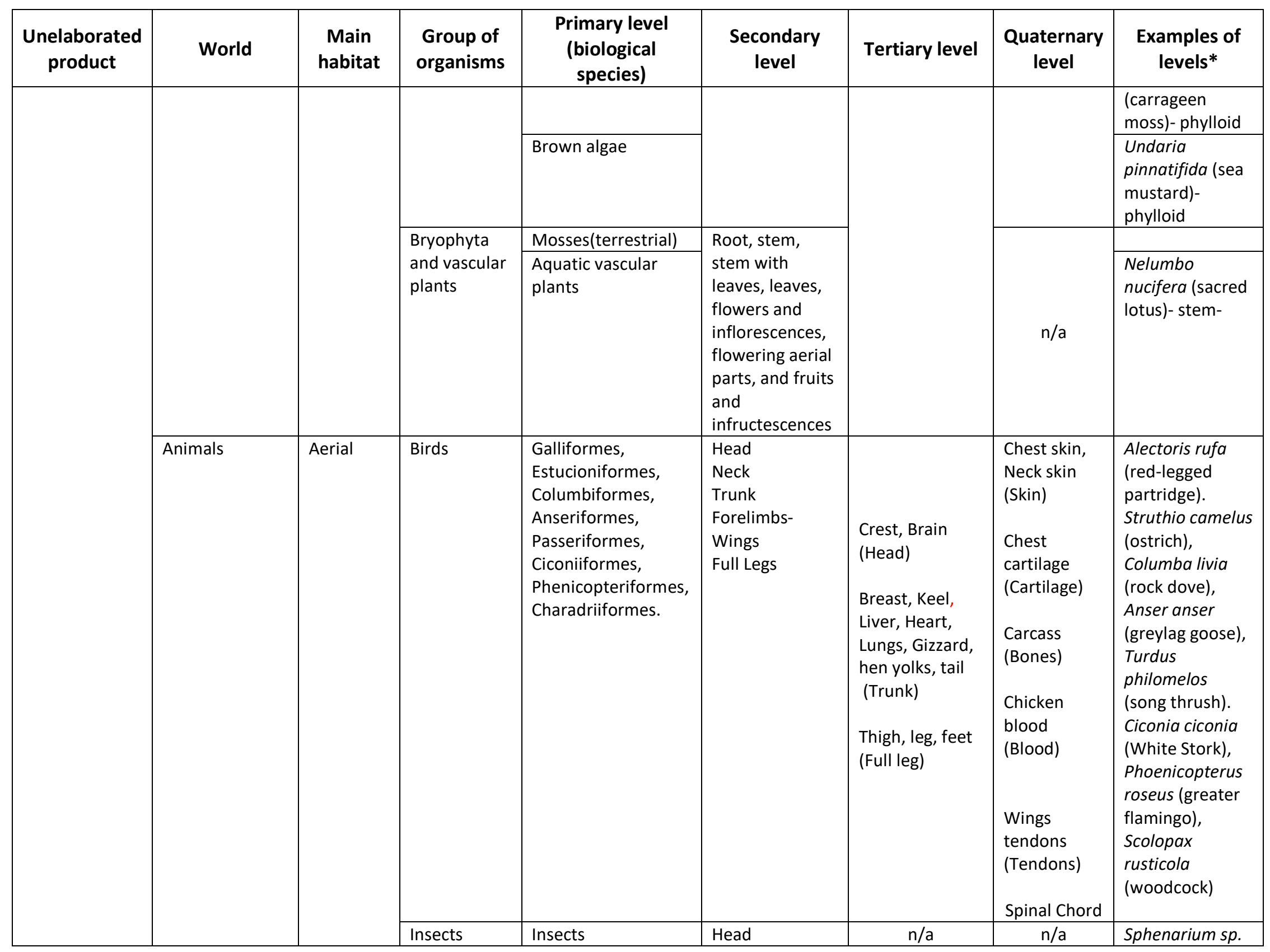




\begin{tabular}{|c|c|c|c|c|c|c|c|c|}
\hline $\begin{array}{l}\text { Unelaborated } \\
\text { product }\end{array}$ & World & $\begin{array}{c}\text { Main } \\
\text { habitat }\end{array}$ & $\begin{array}{l}\text { Group of } \\
\text { organisms }\end{array}$ & $\begin{array}{c}\text { Primary level } \\
\text { (biological } \\
\text { species) }\end{array}$ & $\begin{array}{l}\text { Secondary } \\
\text { level }\end{array}$ & Tertiary level & $\begin{array}{c}\text { Quaternary } \\
\text { level }\end{array}$ & $\begin{array}{c}\text { Examples of } \\
\text { levels* }\end{array}$ \\
\hline & & & & & $\begin{array}{l}\text { Thorax } \\
\text { Abdomen } \\
\text { Extremities }\end{array}$ & & & (grasshopper). \\
\hline & & Terrestrial & Mammals & $\begin{array}{l}\text { Bovine } \\
\text { Ovine } \\
\text { Caprine } \\
\text { Other bovines } \\
\text { Camelids } \\
\text { Cervids } \\
\text { Swine } \\
\text { Equine } \\
\text { Leporidae } \\
\text { Marsupials }\end{array}$ & $\begin{array}{l}\text { Head } \\
\text { Neck } \\
\text { Trunk } \\
\text { Forelimbs } \\
\text { Hind limb } \\
\text { Combinations of } \\
\text { parts } \\
\text { Half carcass } \\
\text { Forequarter } \\
\text { Hindquarter }\end{array}$ & $\begin{array}{l}\text { Snout, Cheek, } \\
\text { Tongue, Brain } \\
\text { (Head) } \\
\text { Brisket } \\
\text { Ribs, Short loin } \\
\text { Sirloin } \\
\text { Rump } \\
\text { Short plate } \\
\text { Flank } \\
\text { Tail } \\
\text { Liver } \\
\text { Heart } \\
\text { Kidneys, } \\
\text { Testicles, } \\
\text { Stomach-guts, } \\
\text { Intestine, udder } \\
\text { (Trunk) } \\
\text { Blade } \\
\text { Chuck } \\
\text { Hock, Hands } \\
\text { (Forelimbs- } \\
\text { Shoulders) } \\
\text { Hock } \\
\text { Topside } \\
\text { Silverside } \\
\text { Eye round, } \\
\text { Outside, } \\
\text { Foot } \\
\text { (Hindlimbs) }\end{array}$ & $\begin{array}{l}\text { Skin } \\
\text { Shoulder } \\
\text { cartilage } \\
\text { (Cartilage) } \\
\text { Bone } \\
\text { marrow } \\
\text { Cannon } \\
\text { bone, Knee } \\
\text { bone, spine } \\
\text { bones } \\
\text { (Bones) } \\
\text { Veal blood } \\
\text { (Blood) } \\
\text { Fat } \\
\text { Limbs } \\
\text { tendons } \\
\text { (Tendons) } \\
\text { Spinal cord, } \\
\text { (Cord) }\end{array}$ & $\begin{array}{l}\text { Bos taurus } \\
\text { (cow), } \\
\text { Ovis aries } \\
\text { (sheep), } \\
\text { Capra hircus } \\
\text { (domestic goat), } \\
\text { Syncerus caffer } \\
\text { (African } \\
\text { buffalo), } \\
\text { Camelus } \\
\text { dromedarius } \\
\text { (dromedary), } \\
\text { Cervus elaphus } \\
\text { (elk), } \\
\text { Sus scrofa (wild } \\
\text { boar), } \\
\text { Equus caballus } \\
\text { (horse), } \\
\text { Oryctolagus } \\
\text { cuniculus } \\
\text { (European } \\
\text { rabbit), } \\
\text { Macropus rufus } \\
\text { (red kangaroo) }\end{array}$ \\
\hline
\end{tabular}




\begin{tabular}{|c|c|c|c|c|c|c|c|c|}
\hline \multirow[t]{6}{*}{$\begin{array}{l}\text { Unelaborated } \\
\text { product }\end{array}$} & \multirow{5}{*}{\multicolumn{2}{|c|}{$\begin{array}{c}\text { Main } \\
\text { habitat }\end{array}$}} & $\begin{array}{l}\text { Group of } \\
\text { organisms }\end{array}$ & $\begin{array}{c}\text { Primary level } \\
\text { (biological } \\
\text { species) }\end{array}$ & $\begin{array}{l}\text { Secondary } \\
\text { level }\end{array}$ & Tertiary level & $\begin{array}{c}\text { Quaternary } \\
\text { level }\end{array}$ & $\begin{array}{c}\text { Examples of } \\
\text { levels* }\end{array}$ \\
\hline & & & Mollusks & Land snails & $\begin{array}{l}\text { Foot with head } \\
\text { Organs } \\
\text { Shell }\end{array}$ & \multirow{4}{*}{$\mathrm{n} / \mathrm{a}$} & \multirow{4}{*}{$\mathrm{n} / \mathrm{a}$} & $\begin{array}{l}\text { Helyx pomatia } \\
\text { (snail) }\end{array}$ \\
\hline & & & $\begin{array}{l}\text { Insects and } \\
\text { other } \\
\text { arthropods }\end{array}$ & $\begin{array}{l}\text { Insects } \\
\text { Other arthropods } \\
\text { (Insects and spiders) }\end{array}$ & $\begin{array}{l}\text { Head } \\
\text { Thorax and } \\
\text { abdomen } \\
\text { Extremities }\end{array}$ & & & $\begin{array}{l}\text { Atta sp. } \\
\text { (ant), } \\
\text { Haplopelma sp. } \\
\text { (spider) }\end{array}$ \\
\hline & & & Reptiles & Reptiles (Lizards) & $\begin{array}{l}\text { Head } \\
\text { Neck } \\
\text { Trunk } \\
\text { Forelimbs } \\
\text { Headquarters } \\
\text { Combinations of } \\
\text { parts }\end{array}$ & & & $\begin{array}{l}\text { Timon lepidus } \\
\text { (jewel lizard) }\end{array}$ \\
\hline & & & Worms & Worms & --- & & & --- \\
\hline & & Aquatic & Fish & $\begin{array}{l}\text { Seawater } \\
\text { Freshwater } \\
\text { Diadroms }\end{array}$ & $\begin{array}{l}\text { Head } \\
\text { Trunk } \\
\text { Fins } \\
\text { Combinations of } \\
\text { parts }\end{array}$ & $\begin{array}{l} \\
\text { Jowls, Cheeks, } \\
\text { Eyes (Head) } \\
\text { Loin, Belly, } \\
\text { Flank, Liver, } \\
\text { Eggs, Gizzard } \\
\text { (Trunk) }\end{array}$ & $\begin{array}{l}\text { Trunk skin, } \\
\text { Fins skin } \\
\text { (Skin) } \\
\text { Head } \\
\text { cartilage } \\
\text { (Cartilage) } \\
\text { Spine- } \\
\text { herringbone, } \\
\text { Fins' spines } \\
\text { (Spines) } \\
\text { Blood } \\
\text { Fat } \\
\text { Tendons }\end{array}$ & $\begin{array}{l}\text { Merluccius } \\
\text { merluccius } \\
\text { (hake), } \\
\text { Salmo trutta } \\
\text { (trout), } \\
\text { Salmo salar } \\
\text { (salmon) }\end{array}$ \\
\hline
\end{tabular}




\begin{tabular}{|c|c|c|c|c|c|c|c|c|}
\hline $\begin{array}{c}\text { Unelaborated } \\
\text { product }\end{array}$ & World & $\begin{array}{c}\text { Main } \\
\text { habitat }\end{array}$ & $\begin{array}{l}\text { Group of } \\
\text { organisms }\end{array}$ & $\begin{array}{c}\text { Primary level } \\
\text { (biological } \\
\text { species) }\end{array}$ & $\begin{array}{l}\text { Secondary } \\
\text { level }\end{array}$ & Tertiary level & $\begin{array}{c}\text { Quaternary } \\
\text { level }\end{array}$ & $\begin{array}{l}\text { Examples of } \\
\text { levels* }\end{array}$ \\
\hline & & & & & & & Cord & \\
\hline & & & Mollusks & $\begin{array}{l}\text { Seawater: } \\
\text { Bivalves } \\
\text { Gastropods } \\
\text { Cephalopods } \\
\text { Freshwater: } \\
\text { Bivalves } \\
\text { Gastropods }\end{array}$ & $\begin{array}{l}\text { Mantle (meat) } \\
\text { Organs } \\
\text { Shell }\end{array}$ & Food (Mantle) & \multirow{5}{*}{$\mathrm{n} / \mathrm{a}$} & $\begin{array}{l}\text { Mytilus edulis } \\
\text { (mussel), } \\
\text { Bolinus } \\
\text { brandaris } \\
\text { (sea snail), } \\
\text { Sepia officinalis } \\
\text { (sepia) }\end{array}$ \\
\hline & & & $\begin{array}{l}\text { Crustaceans } \\
\text { and other } \\
\text { arthropods }\end{array}$ & $\begin{array}{l}\text { Seawater: } \\
\text { Swimmers } \\
\text { Walkers } \\
\text { Cirripedes } \\
\text { Freshwater: } \\
\text { Swimmers }\end{array}$ & $\begin{array}{l}\text { Cephalothorax } \\
\text { (head) } \\
\text { Abdomen (Tail) } \\
\text { Extremities } \\
\text { Nail or upper } \\
\text { part } \\
\text { Peduncle or } \\
\text { bottom part } \\
\text { Cephalothorax } \\
\text { (head) } \\
\text { Abdomen (Tail) } \\
\text { Extremities }\end{array}$ & $\begin{array}{l}\text { Digestive } \\
\text { system, shell, } \\
\text { head } \\
\text { (Cephalothorax) } \\
\text { Muscle (meat), } \\
\text { Shell } \\
\text { (Abdomen) }\end{array}$ & & $\begin{array}{l}\text { Palinurus } \\
\text { elephas } \\
\text { (bobster), } \\
\text { Necora puber } \\
\text { (necora), } \\
\text { Pollicipes } \\
\text { cornucopia } \\
\text { (barnacle) } \\
\\
\text { Procambarus } \\
\text { clarkii } \\
\text { (red swamp } \\
\text { crawfish) }\end{array}$ \\
\hline & & & Echinoderms & Seawater & $\begin{array}{l}\text { Shell } \\
\text { Organs }\end{array}$ & \multirow{3}{*}{$\mathrm{n} / \mathrm{a}$} & & $\begin{array}{l}\text { Paracentrotus } \\
\text { lividus } \\
\text { (sea urchin) }\end{array}$ \\
\hline & & & Cnidarians & Seawater & $\begin{array}{l}\text { Tentacles } \\
\text { Organs }\end{array}$ & & & $\begin{array}{l}\text { Anemonia viridis } \\
\text { (sea anemone) }\end{array}$ \\
\hline & & & Tunicates & Seawater & $\begin{array}{l}\text { Mantle (meat) } \\
\text { Tunic }\end{array}$ & & & $\begin{array}{l}\text { Microcosmus } \\
\text { sabatieri } \\
\text { (sea squirt) } \\
\end{array}$ \\
\hline & & & Mammals & $\begin{array}{l}\text { Seawater } \\
\text { Freshwater }\end{array}$ & $\begin{array}{l}\text { Head } \\
\text { Trunk } \\
\text { Fins } \\
\text { Combinations of }\end{array}$ & $\begin{array}{l}\text { Loin, Belly, } \\
\text { Liver, Heart } \\
\text { (Trunk) }\end{array}$ & $\begin{array}{l}\text { Trunk skin, } \\
\text { Fins skin } \\
\text { (Skin) }\end{array}$ & $\begin{array}{l}\text { Delphinus } \\
\text { delphis } \\
\text { (common } \\
\text { dolphin), }\end{array}$ \\
\hline
\end{tabular}




\begin{tabular}{|c|c|c|c|c|c|c|c|c|}
\hline $\begin{array}{l}\text { Unelaborated } \\
\text { product }\end{array}$ & World & $\begin{array}{l}\text { Main } \\
\text { habitat }\end{array}$ & $\begin{array}{c}\text { Group of } \\
\text { organisms }\end{array}$ & $\begin{array}{l}\text { Primary level } \\
\text { (biological } \\
\text { species) }\end{array}$ & $\begin{array}{c}\text { Secondary } \\
\text { level }\end{array}$ & Tertiary level & $\begin{array}{c}\text { Quaternary } \\
\text { level }\end{array}$ & $\begin{array}{l}\text { Examples of } \\
\text { levels* }\end{array}$ \\
\hline & & & & & parts & & $\begin{array}{l}\text { Cartilage } \\
\text { Backbone, } \\
\text { Fins' bones } \\
\text { (Bones) } \\
\text { Whale blood } \\
\text { (Blood) } \\
\text { Sebum (Fat) } \\
\text { Tendons } \\
\text { Marrow } \\
\text { (Cord) }\end{array}$ & $\begin{array}{l}\text { Sotalia fluviatilis } \\
\text { (gray dolphin) }\end{array}$ \\
\hline & & $\begin{array}{l}\text { Terrestrial } \\
\text { and } \\
\text { aquatic }\end{array}$ & Amphibians & Amphibians (Frogs) & $\begin{array}{l}\text { Head } \\
\text { Neck } \\
\text { Trunk } \\
\text { Forelimbs } \\
\text { Combinations of } \\
\text { parts }\end{array}$ & \multirow[b]{2}{*}{$\mathrm{n} / \mathrm{a}$} & \multirow[b]{2}{*}{$\mathrm{n} / \mathrm{a}$} & $\begin{array}{l}\text { Pelophylax } \\
\text { perezi } \\
\text { (common frog) }\end{array}$ \\
\hline & & & Reptiles & $\begin{array}{l}\text { Reptiles (Crocodiles, } \\
\text { Turtles) }\end{array}$ & $\begin{array}{l}\text { Head } \\
\text { Neck } \\
\text { Trunk } \\
\text { Forelimbs } \\
\text { Headquarters } \\
\text { Shell } \\
\text { Combinations of } \\
\text { parts }\end{array}$ & & & $\begin{array}{l}\text { Alligator } \\
\text { mississipiensis } \\
\text { (alligator) }\end{array}$ \\
\hline & \multirow[t]{2}{*}{ Microorganisms } & & \multirow[t]{2}{*}{ Bacteria } & Wild & $\begin{array}{l}\text { Lactic or acetic } \\
\text { fermenting } \\
\text { bacteria }\end{array}$ & \multirow[t]{2}{*}{$n / a$} & \multirow[t]{2}{*}{$\mathrm{n} / \mathrm{a}$} & Lactobacillus sp. \\
\hline & & & & Cultured & $\begin{array}{l}\text { Lactic or acetic } \\
\text { fermenting }\end{array}$ & & & Acetobacter sp. \\
\hline
\end{tabular}




\begin{tabular}{|c|c|c|c|c|c|c|c|c|}
\hline $\begin{array}{c}\text { Unelaborated } \\
\text { product }\end{array}$ & World & $\begin{array}{c}\text { Main } \\
\text { habitat }\end{array}$ & $\begin{array}{l}\text { Group of } \\
\text { organisms }\end{array}$ & $\begin{array}{c}\text { Primary level } \\
\text { (biological } \\
\text { species) }\end{array}$ & $\begin{array}{c}\text { Secondary } \\
\text { level }\end{array}$ & Tertiary level & $\begin{array}{c}\text { Quaternary } \\
\text { level }\end{array}$ & $\begin{array}{c}\text { Examples of } \\
\text { levels* }\end{array}$ \\
\hline & & & & & bacteria & & & \\
\hline & & & \multirow[t]{4}{*}{ Microfungi } & \multirow[t]{2}{*}{ Yeasts } & Wild & \multirow{4}{*}{$n / a$} & \multirow{4}{*}{$\mathrm{n} / \mathrm{a}$} & \multirow{2}{*}{$\begin{array}{l}\text { Saccharomyces } \\
\text { sp. }\end{array}$} \\
\hline & & & & & Cultured & & & \\
\hline & & & & \multirow[t]{2}{*}{ Molds } & Wild & & & \multirow{2}{*}{ Penicillium sp. } \\
\hline & & & & & Cultured & & & \\
\hline & & & \multirow{2}{*}{ Microalgae } & Wild & \multirow{2}{*}{$\mathrm{n} / \mathrm{a}$} & \multirow{2}{*}{$\mathrm{n} / \mathrm{a}$} & \multirow{2}{*}{$\mathrm{n} / \mathrm{a}$} & \multirow{2}{*}{ Chlorella sp. } \\
\hline & & & & Cultured & & & & \\
\hline & $\begin{array}{l}\text { Derivatives ( } \\
\text { se) }\end{array}$ & vorld per & \multicolumn{5}{|c|}{ Considered for each world and group of organisms } & $\begin{array}{l}\text { From plants: } \\
\text { Gums, resins, } \\
\text { mastic } \\
\text { From animals: } \\
\text { Fresh milk, fresh } \\
\text { eggs, honey } \\
\text { From } \\
\text { microorganisms } \\
\text { Xanthan gum }\end{array}$ \\
\hline
\end{tabular}

*For each world, the column 'examples of levels' corresponds to distinct levels, beginning with the primary, and separated with a hyphen from following levels. n/a: Non-applicable. 
Table 2: Classification of unelaborated products: inorganic materials

\begin{tabular}{|c|c|c|c|c|c|}
\hline $\begin{array}{l}\text { Unelaborated } \\
\text { product }\end{array}$ & World & Origin & Sub-origin & Type & Examples \\
\hline \multirow[t]{8}{*}{$\begin{array}{l}\text { Inorganic } \\
\text { materials }\end{array}$} & \multirow[t]{6}{*}{ World of waters } & \multirow[t]{3}{*}{ Superficial } & River & \multirow[t]{3}{*}{ Non-carbonated } & $\begin{array}{l}\text { Prepared water from } \\
\text { public supply }\end{array}$ \\
\hline & & & Lake & & $\begin{array}{l}\text { Prepared potable } \\
\text { water }\end{array}$ \\
\hline & & & Glacier & & $\begin{array}{l}\text { Glacier water of weak } \\
\text { mineralization }\end{array}$ \\
\hline & & \multirow[t]{2}{*}{ Subterraneous } & Natural mineral & \multirow[t]{2}{*}{$\begin{array}{l}\text { Non-carbonated or } \\
\text { carbonated }\end{array}$} & $\begin{array}{l}\text { Ferruginous natural } \\
\text { mineral water }\end{array}$ \\
\hline & & & Natural spring & & $\begin{array}{l}\text { Decarbonated spring } \\
\text { water }\end{array}$ \\
\hline & & Seawater & & & Deep seawater \\
\hline & \multirow[t]{2}{*}{$\begin{array}{l}\text { World of minerals } \\
\text { (salt) }\end{array}$} & Fossil & & $\begin{array}{l}\text { In white, pink or black } \\
\text { rock }\end{array}$ & $\begin{array}{l}\text { Himalayan pink salt } \\
\text { Sanchal black salt }\end{array}$ \\
\hline & & Salt lakes and salt flats & & $\begin{array}{l}\text { Fine common salt, } \\
\text { coarse common salt, } \\
\text { flower of salt, or salt } \\
\text { flakes }\end{array}$ & $\begin{array}{l}\text { Hawaiian salt, Maldon } \\
\text { salt }\end{array}$ \\
\hline
\end{tabular}


Table 3: Overall classification of major culinary elements in an increasing ranking order

\begin{tabular}{|c|c|c|c|c|}
\hline $1^{\text {st }}$ rank & $2^{\text {nd }}$ rank & $3^{\text {rd }}$ rank - Worlds & $\begin{array}{c}4^{\text {th }} \text { rank - Levels \& } \\
\text { categories }\end{array}$ & Example of primary level \\
\hline \multirow[t]{5}{*}{$\begin{array}{l}\text { Unelaborated } \\
\text { products }\end{array}$} & \multirow[t]{3}{*}{ Living beings } & Plants and fungi & $\begin{array}{l}\text { Primary to up to tertiary } \\
\text { levels }\end{array}$ & $\begin{array}{l}\text { Apple tree (Malus domestica) } \\
\text { Portobello mushroom (Agaricus bisporus) }\end{array}$ \\
\hline & & Animals & $\begin{array}{l}\text { Primary to up to quaternary } \\
\text { levels }\end{array}$ & Brown trout (Salmo trutta) \\
\hline & & Microorganisms & $\begin{array}{l}\text { Primary to up to secondary } \\
\text { levels }\end{array}$ & Yeast (Saccharomyces cerevisiae) \\
\hline & \multirow{2}{*}{$\begin{array}{l}\text { Inorganic } \\
\text { materials }\end{array}$} & Waters & - & Spring water $\left(\mathrm{H}_{2} \mathrm{O}\right)$ \\
\hline & & Minerals & - & Sea salt ( $\mathrm{NaCl}$ and other salts) \\
\hline
\end{tabular}




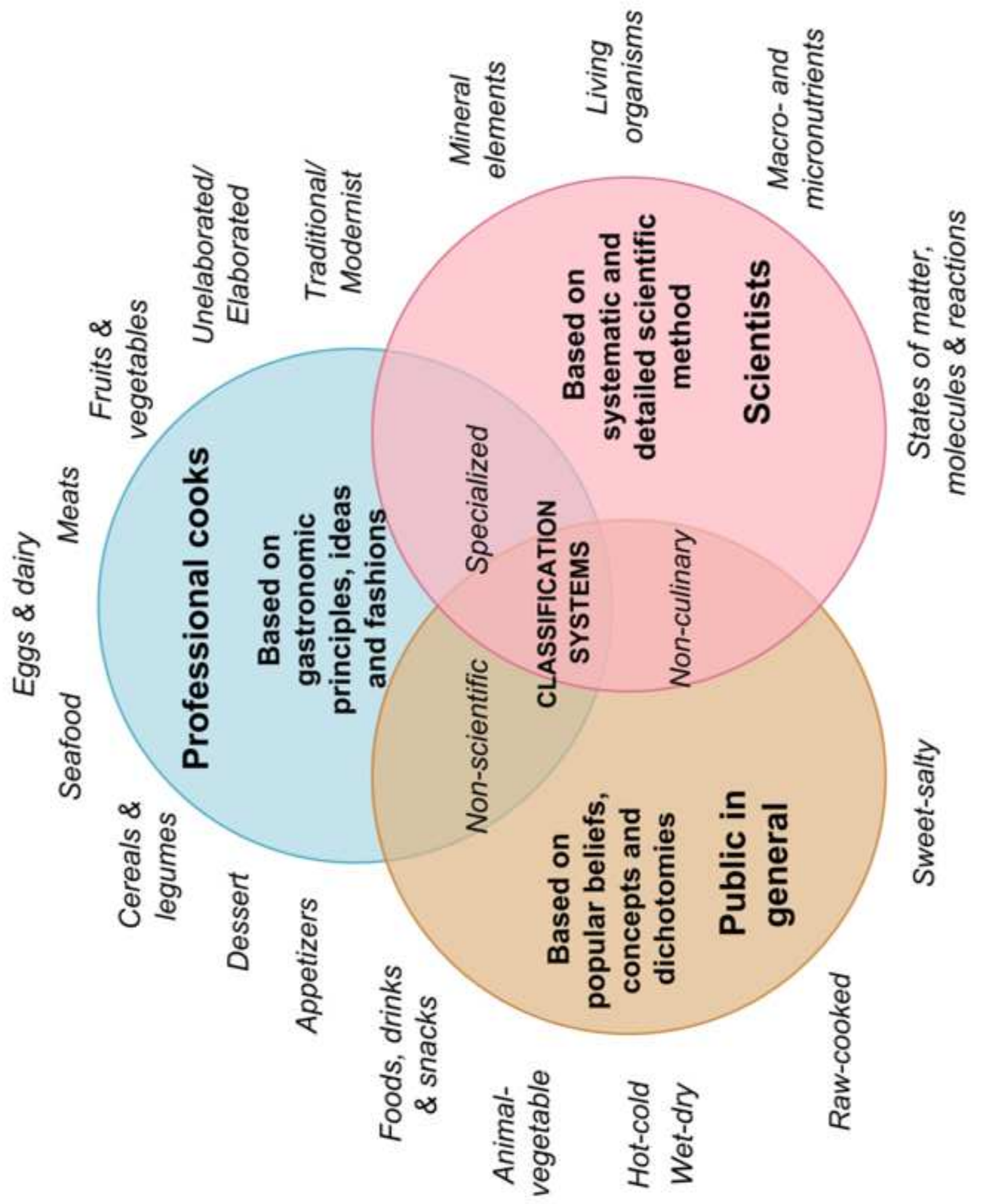

